\title{
CANCIÓN DE LA VERDAD SENCILLA: JULIA DE BURGOS Y SU DIÁLOGO ERÓTICO-MÍSTICO CON LA NATURALEZA
}

\author{
POR \\ CARLOTA CAULFIELD \\ Tulane University
}

En Canción de la verdad sencilla, de Julia de Burgos, la experiencia erótica se manifiesta como una vía fundamental que conduce hacia la comunión con la totalidad de la vida y de la naturaleza. El erotismo en este libro de poemas ${ }^{1}$ permite la reconciliación del sujeto y del mundo y, a partir de ésta, la fusión del alma y del cuerpo. Como los místicos, Julia de Burgos en sus versos desata los nudos que le impiden lograr su despertar. Los desata mientras expone la intensidad de su pasión amorosa, y explora a la mujer y a la artista que viven dentro de ella. La experiencia poética lleva a Burgos a estados contemplativos en los cuales se produce su experiencia mística. Ambas experiencias se comunican recíprocamente y se revitalizan la una con la otra. Así, en la escritura del poema se produce una plenitud de carácter erótico-mística.

En Canción, cuando Burgos explora sus sensaciones en un viaje dentro de sí misma, se descubre unida al universo. ${ }^{2}$ Su recorrido es esencialmente un canto a la naturaleza, a quien siente poseer a través del amado a la vez que lo posee a él a través de ésta. ${ }^{3}$ Burgos entabla un diálogo con la naturaleza para

\footnotetext{
1 Julia de Burgos, Canción de la verdad sencilla (Río Piedras: Ediciones Huracán, 1982). Esta edición no incluye ni la segunda ni la tercera parte del libro tal y como fue publicado en 1939 por la Imprenta Baldrich de San Juan. En realidad, cada parte del libro puede considerarse un poemario independiente. La segunda parte está formada por "Los poemas del río" y la tercera parte lleva el título de "Confesión del sí y del no".

${ }^{2}$ Burgos parece compartir en sus poemas la idea filos ffica monista que concibe al universo como sustancia única de la cual proceden todas las cosas y con la cual se identifican. El monismo se confunde muchas veces con el panteísmo para el cual Dios y el universo son uno solo. Véase William L. Reese, Dictionary of Philosophy and Religion (New Jersey: Humanities Press, 1980) 366 y 409-410.

${ }^{3}$ El sensualismo que Burgos logra en estos poemas es muy cercano al de muchos poetas arábigoandaluces como Abenalzaccac de Valencia, Abensáfar de Almería y Abenházan de Córdoba. El poeta árabe identifica frecuentemente el amor y al ser amado con la naturaleza. La posesion del ser amado significa para el poeta poseer la naturaleza. Véase Emilio García Gómez, Poemas arábigoandaluces (Madrid: Editorial Plutarco, 1930).
} 
verbalizar su biografía amorosa. ${ }^{4}$ En este diálogo la naturaleza le responde a la poeta con imágenes que ésta hace suyas para expresar, a través de ellas, la gama de sus emociones. De esta forma en Canción Burgos parece compartir la idea expresada por la escritora y pensadora francesa Simone Weil de "s'identifier à l'univers même. Tout ce qui est moindre que l'univers est soumis à la souffrance.".5

En Canción de la verdad sencilla, Burgos construye un espacio poético a partir de "la confesión intima de una mujer con plena conciencia de todos los accidentes del ser". ${ }^{6}$ Burgos convierte a la naturaleza en su mejor cómplice para encontrar la plenitud espiritual y física con el amado, ese Otro que representa la esencia del amor. La naturaleza es para ella el símbolo de todo lo trascendente; es el foro donde la mujer reconoce al hombre.

En el poema "Canción sublevada" la identificación de Burgos con la naturaleza se da mediante una alocución al amante para que éste despierte a las emociones de la voz poética:

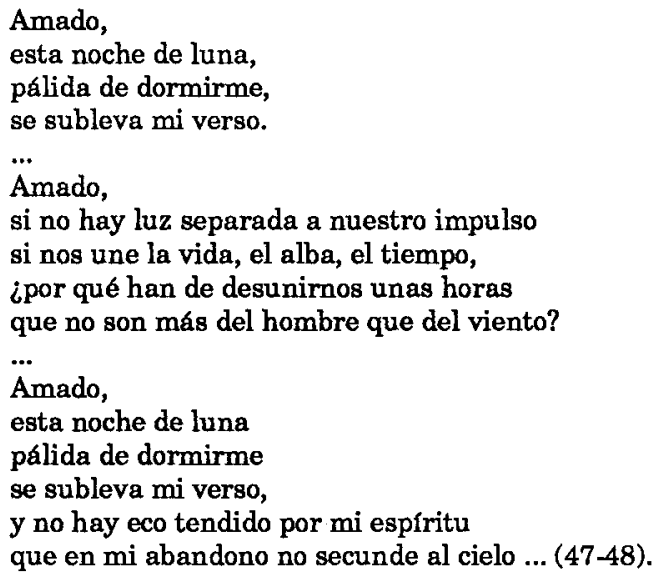

El erotismo de la pasión amorosa vibra en los poemas de Canción. En "Canción para llorar y amar", Burgos penetra en la naturaleza y recrea su amor por el Otro en la tierra fértil que muestra sus frutos:

4 La poesía amorosa de Burgos no está desvinculada de la poesía amorosa de Clara Lair ni tampoco de la obra de Delmira Agustini, Juana de Ibarbourou y Alfonsina Storni. En muchos de sus versos, estas poetas también erotizan la naturaleza. Véase José Emilio González, La poesía contemporánea de Puerto Rico 1930-1960 (San Juan: Instituto de Cultura Puertorriqueña, 1972), 337, 352 y 357-358.

- Simone Weil, La pesanteur et la grâce (Paris: Plon, 1946) 141.

- Nelly E. Santos, "El itinerario temático de Julia de Burgos: el amor y la muerte". Cuadernos Americanos 203 (1975) 236. 


\author{
Mi alma abrí a tu alma \\ como el abrir humilde de una estrella, \\ y me doblé a tu vida \\ como inclina su peso hacia la tierra \\ la espiga fecundada (55).
}

El acto de inclinación de la espiga hacia la tierra se transforma aquí en un acto de comunión con lo telúrico mediante el cual mujer y espiga se hacen una. La voz poética participa en el proceso de preservar e incluso crear la vida. Así, el poema asume la función de la vida engendrada en la matriz creadora de la poeta. La formación de una nueva vida, llámese en este caso poesía, no es un acto de disfrute pleno, sino que conlleva sufrimiento. Dice Burgos "Desde allí / dolor y amor me llevan / sujeta la emoción" (55).

Las dualidades que constantemente acechan a la poeta no impiden en ningún momento su autocontemplación y su identificación con la naturaleza. Las dicotomías entre lo imaginario y lo real más que erosionar, vigorizan la expresión de estos poemas. El poema es el campo de batalla donde se libra la lucha entre la vida y la muerte, la alegría y la tristeza, el placer y el dolor. Es también en el poema donde estos opuestos llegan a reconciliarse. Así en "Canción para llorar y amar" no hay miedo de equivocar el camino escogido que tiene como punto de destino al Otro:

¡Qué simple es la conciencia

ante el reclamo cósmico

que ha cruzado mi espíritu!

Me he encontrado la vida

al ascender mi castidad de impulso, contigo en ti y en todo (55).

El acto de identificación con las potencias fecundantes del universo ${ }^{7}$ queda mejor plasmado en "Noche de amor en tres cantos" cuando la poeta dice:

¡Cómo siento que estoy en tu carne cual espiga a la sombra del astro! ¡Cómo siento que llego a tu alma y que allá tú me estás esperando! (23).

Se ha producido aquí el equilibrio entre la naturaleza y el amor. La comunicación entre el ser que ama y el ser amado se encamina hacia su plenitud. El ser es uno antes y otro distinto después de la llegada del amor. El amor en estos poemas de Burgos tiene la función de transformar, de integrar, y, a la vez, de emancipar.

\footnotetext{
7 José Emilio González, Poesía contemporánea ..., 346.
} 
En "Poema detenido de un amanecer", se producen tres momentos del yo poético que muy bien pudieran relacionarse con las tres vias por las cuales pasa el místico para que su alma logre la unión con la divinidad. ${ }^{8}$ No olvidemos que gran parte de la literatura mística posee un carácter ambiguo que permite que ésta pueda leerse tanto como poesía religiosa o como poesía erótica. ${ }^{9}$ En definitiva, la entrega amorosa del místico a Dios no es muy diferente a la entrega plena entre los amantes.

En los textos de Burgos, el primer momento es el de la identificación del yo poético con el universo sin que intervengan otros elementos ajenos. El ser y la naturaleza poseen un aura de beatitud, de nada, de vacio; una voluntad de autoanálisis que lleva a Burgos a confesar la frustración que quiere callar:

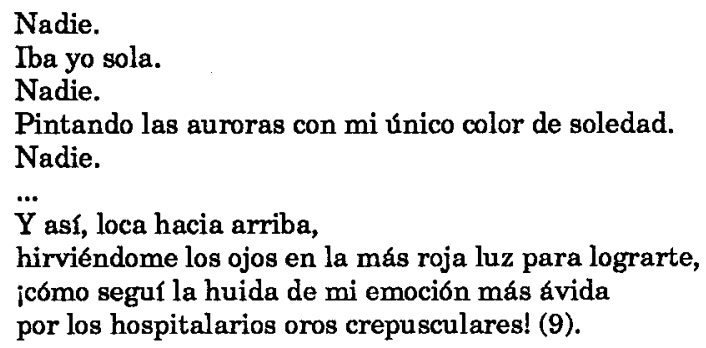

El segundo estado relaciona al yo poético con el universo en el gradual alejamiento del caos de sensaciones. Gracias a la meditación y a la contemplación la poeta acepta su soledad como una forma de iluminación:

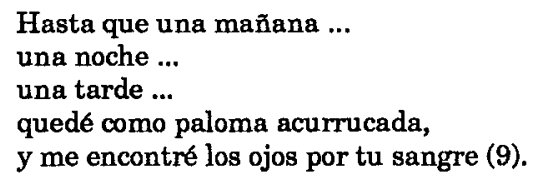

El conocimiento anticipado de la plenitud amorosa deseada se produce al final del poema como un chispazo de luz. La realidad circundante se va quedando en el olvido mientras la voz poética se manifiesta en la totalidad de

\footnotetext{
${ }^{8}$ La primera vía que recorre el místico es la purgativa. Es el paso de iniciación y la voluntad es decisiva para encaminar el espíritu hacia su perfección. En la segunda vía llamada también iluminativa se produce el despertar espiritual sin que medie la voluntad. La via unitiva es la última fase en la que se produce la plena comunicación con Dios. Véase Fr. Juan G. Arintero, La evolución mistica (Madrid: Biblioteca de Autores Cristianos, 1952) 350-366.

${ }^{9}$ Willis Barnstone, "Saint John of the Cross. Mystico-Erotic Love in 'O Living Flame of Love". The Poetics of Ecstasy (New York: Holmes \& Meir, 1983) 180-190.
} 
su ímpetu pasional. El movimiento del poema va desde una invocación hasta un éxtasis que simboliza con imágenes de la naturaleza:

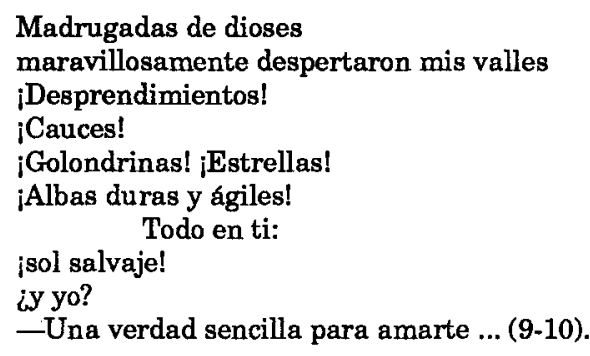

El amor penetra y se sumerge en la voz poética hasta producir una divina plenitud que la transforma. El ser incompleto se complementa con el Otro. El éxtasis emocional en estos versos conlleva también, como en algunas manifestaciones místicas, cierta violencia espiritual y física. Esto puede verse cuando San Juan de la Cruz escribe que en la unión plena con Dios se siente el espíritu, de pronto, invadido por un atronador torrente de agua:

que de tal manera se ve el alma envestir del torrente del espíritu de Dios en este caso y con tanta fuerza apoderarse de ella, que le paresce que vienen sobre ella todos los rios del mundo ...10

El yo poético en su total desnudez, queda al final de "Poema detenido en un amanecer" convertido en "una verdad sencilla" que se podría relacionar con un estado de gracia. En "Poema del minuto blanco" se manifiesta ese estado de punto cero:

Fue una actitud de éxtasis desnuda en el misterio ...

Los ojos se me fueron perdiendo de sus órbitas y cayendo en su centro ...

Una quietud de rocas se filtró por mis poros y escondió mis revuelos.

Transparente de esencias se rodó en el instante mi emoción y mi cuerpo;

y fue el minuto blanco, más allá de mi vida, empujándome al cielo (39).

${ }^{10}$ San Juan de la Cruz, El cántico espiritual (Madrid: Espasa-Calpe, 1944) 112. 
Con frecuencia, en la poesía de Burgos, la naturaleza se identifica con el agua. De la misma forma que el filósofo monista Tales de Mileto vio al agua como el principio unificador del universo, para Burgos el agua es "principio y fin de todas las cosas de la tierra". " En el poema "Canción de la verdad sencilla" el "tú" y el "yo" se convierten en un solo ente gracias al agua convertida en manantial:

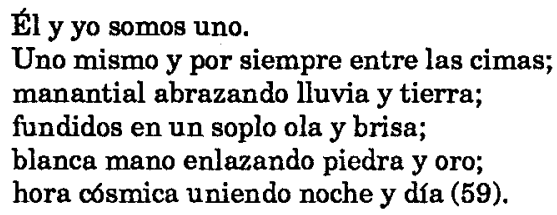

El manantial es en estos versos la fuente donde la voz poética se declara portadora de todas las demás voces de la naturaleza. De la misma forma en que la poeta se funde con su amado, así se funden los elementos de la naturaleza en la poesía de Burgos.

En "Transmutación", la idea del sentir amoroso vuelve a quedar asociada plenamente con la vuelta a lo telúrico. La voz poética ve signos del amado en la naturaleza:

Estoy sencilla como la claridad ...

Nada me dice tanto como tu nombre repetido de montaña a montaña

por un eco sin tiempo que comienza en mi amor

y rueda al infinito...

Tú lo dominas todo para mi claridad.

Y soy simple destello en albas fijas amándote ... (13).

Sin embargo, estos indicios del amado no hacen su retrato. En casi todos estos poemas el amado aparece como una figura borrosa. Esto tal vez explique la necesidad de desplazar su erotismo a la naturaleza. En "Noche de amor en tres cantos" es el único momento de Canción en el que el amado parece poseer cierta ternura. Es en estos versos en los que Burgos logra su más vehemente expresión poética. El primer canto se titula "Ocaso" y en él se define el clímax erótico de todo el poema:

¡C6mo suena en mi alma la idea

de una noche completa en tus brazos

diluyéndome toda en caricias

mientras tú te me das extasiado!

...

${ }^{11}$ Nelly Santos, “Itinerario...". CA 203 (1975) 238-239. 
¡C6́mo siento mi amor floreciendo en la mística voz de tu canto: notas tristes y alegres y hondas que unirán tu emoción a tu rapto! (22)

En el segundo canto o "Media noche" las fronteras entre las sensaciones físicas y las espirituales se borran:

Mis pequeñas palomas se salen de su nido de anhelos extraños y caminan su forma tangible hacia el cielo ideal de tus manos.

...

Se han unido, mi amor, se han unido nuestras risas más blancas que el blanco, y joh milagro! en la luz de una lágrima se han besado tu llanto y mi llanto ... (23).

Del cuerpo y sus sensaciones Burgos regresa a las sensaciones del espíritu y logra que las fronteras vuelvan a precisarse. El mismo itinerario de la naturaleza al yo poético y del yo poético al amor se repite obstinadamente. Eros surge victoriosamente mientras Tanatos se recrea en el placer de la plenitud:

¡Cómo muero las últimas millas que me ataban al tren del pasado! ¿Qué frescura me mueve a quedarme en el alba que tú me has brindado! (23-24).

En la órbita del yo poético con la naturaleza surge el tercer canto o "Alba". Aquí Burgos vuelve a identificar el amor con el acto de creación de vida. La tierra es dadora y la mujer recoge los frutos que no son sino sus sensaciones:

La ternura de todos los surcos se ha quedado enredada en mis pasos, y los dulces instantes vividos siguen, tenues, en mi alma soñando ...

...

Ya la noche se fue; y las nuevas emociones del alba se ha atado.

Todo sabe a canciones y a frutos, $y$ hay un niño de amor en mi mano.

Se ha quedado tu vida en mi vida como el alba se queda en los campos; y hay mil pájaros vivos en mi alma de esta noche de amor en tres cantos ... (24-25). 
El tema esencial de Canción es el descubrimiento del amor como gestador de creación y plenitud vital. Sin embargo, la voz poética entra por momentos en un estado de desequilibrio ante el desamor y el extrañamiento del ser amado. Una consecuencia de esto es que el diálogo de Burgos con la naturaleza se manifieste en dos niveles; uno que posee una sensualidad propia, y otro que se recrea en la dualidad de la fragmentación ontológica. El yo poético se hace bipartito entre unión y desunión con el universo. Sin embargo, vuelve a encontrar su equilibrio. Estos cambios del yo poético pueden apreciarse en el poema "Insomne".. La sensación de nada no se da ahora en términos de entrega total entre los amantes, sino como "a thirst, an unsatisfaction, a feeling of incompletion" . ${ }^{12}$ El vacío produce una tensión emocional que se convierte en una pregunta que en ningún momento es capitulación:

Camino ...

En puntos suspensivos de dolor anudo tu distancia.

El aire se me pierde.

¿Qué te separa de mis ojos

destrozados y débiles?

¿Cómo no estás aquí,

-vida por mi poema-

diluyéndote? (40).

En conclusión, Canción de la verdad sencilla es un poemario que conjuga la euforia y el duelo de la experiencia amorosa. El diálogo con la naturaleza le sirve a Julia de Burgos para examinar su erotismo y descubrir su espiritualidad mientras asume la creación poética como el espacio más auténtico en el que se reconoce, se define y crea su destino.

12 Elpidio Laguna-Diaz, "The Phenomenology of Nothingness in the Poetry of Julia de Burgos". Latin American Women Writers: Yesterday and Today. Yvette E. Miller y Charles M. Tatum, eds. (Pittsburgh: Latin American Literary Review, 1977) 130. 